\title{
The Influence of Demographic, Financial Literacy and Information Factors on Investment Decision Among Millenial Generations in Bandung
}

\author{
Yustitia Fitria, Raden Aswin Rahadi, Kurnia Fajar Afgani, Nur Arief R. Putranto, \\ Isrochmani Murtaqi, and Taufik Faturohman
}

\begin{abstract}
Financial literacy is very important for someone in making decisions, especially those relating to daily activities such as in making decisions to save or invest to achieve a predetermined goal. Having good financial literacy will reduce the number of victims in the name of investment. In 2018 the Indonesian stock exchange stated that in 2018 the increase in the number of registered investors increased by $31.97 \%$ and an increase in the average number of active investors in trade compared to the end of 2017. From a total of 168 respondents, $61.76 \%$ had implemented financial management. Of the various types of financial management activities by investing in the capital market chosen by millennials, there are $54.41 \%$. The author has a strong belief that demographic factors and many other factors vary to define investment management decisions. To conduct this research by collecting primary data by distributing questionnaires and secondary data from relevant journals, textbooks, and research publications. Data will be analyzed using descriptive statistics with the classic assumption test method using 5 types of tests. From the results of this study the authors aim to find out how many the factors above influence the decision to invest among millennial generations in Bandung.
\end{abstract}

Index Terms - Demographic, Financial Knowledge, Financial Literacy, Investment Decision, Millennial.

\section{INTRODUCTION}

Financial literacy is very important for someone in making decisions, especially those related to daily activities such as in deciding to save (investment) or investment (Investment) to achieve a predetermined goal. It is not only giving advantages for an individual but also support a

Published on November 27, 2019

Yustitia Fitria is with the School of Business and Management, Institut Teknologi Bandung, Jl. Ganesha No. 10 Bandung 40132, West Java, INDONESIA (e-mail: yustitia_fitria@sbm-itb.ac.id)

Raden Aswin Rahadi is with the School of Business and Management, Institut Teknologi Bandung, Jl. Ganesha No. 10 Bandung 40132, West Java, INDONESIA (e-mail: aswin.rahadi@sbm-itb.ac.id)

Kurnia Fajar Afgani is with the School of Business and Management, Institut Teknologi Bandung, Jl. Ganesha No. 10 Bandung 40132, West Java, INDONESIA (e-mail: kurnia.fajar@sbm-itb.ac.id)

Nur Arief R. Putranto is with the School of Business and Management, Institut Teknologi Bandung, Jl. Ganesha No. 10 Bandung 40132, West Java, INDONESIA (e-mail: nur.arief@sbm-itb.ac.id)

Isrochmani Murtaqi is with the School of Business and Management, Institut Teknologi Bandung, Jl. Ganesha No. 10 Bandung 40132, West Java, INDONESIA (e-mail: nani@sbm-itb.ac.id)

Taufik Faturohman is with the School of Business and Management, Institut Teknologi Bandung, Jl. Ganesha No. 10 Bandung 40132, West Java, INDONESIA (e-mail: taufik.f@sbm-itb.ac.id) country's economic system sustainability. Based on the results of a survey conducted by Financial Services Authority in 2016 the level of financial literacy in Indonesia was divided into 4 levels, namely "Well Literate", "Enough Literate", "Less Literate", "Not Literate". And from the survey results, only $29.66 \%$ increased by $8 \%$ from 2013 which was only $21.84 \%$ of the Indonesian community included in the well literate category.

Yet, the condition of the Indonesian capital market in the past 3 years is experiencing significant growth. For three years from 2015 to 2018 IHSG movements tended to strengthen. Based on information from KSEI's President Director Frederica Widyasari, the number of investors in the Indonesian Capital Market refers to the number of Single Investor Identification (SID) and recorded Based on KSEI data as of 19 November 2018, the total number of stock investors on IDX has reached 829,426 SID. This number increased $31.97 \%$ compared to the total achievement of the number of investors at the end of 2017 amounting to 628,491 SID. The increasing number of new investors entering the capital market will be a good signal to advance and improve the conditions of the Indonesian capital market. Because the improvement in the Indonesian capital market will attract investors to invest in the capital market.

\section{METHODS}

\section{A. Conceptual Framework}

Conceptual framework for this research started from issue among people. Recently the Indonesian capital market has been growing rapidly. This attracts the author to conduct research on what factors have a significant influence on the development of capital markets in Indonesia. To conduct research, the authors found several factors that generally influence a person's decision to invest in the capital market so that it can lead to developments in the Indonesian capital market.

\section{B. Data Collection and Analysis}

The data collected were primary and secondary data that will be analysis to get the results of the research. From the result, the researcher will make the conclusion and give the recommendation relevant to the research. The primary data is data that originally collected by the researcher for a specific research purpose [1]. On this research for collected the primary data the author collected by distributing questionnaires and targeting Bandung area society as the 
population of the research. Thus, for the samples of this research are people who live in Bandung which representing the Bandung society. The data that will be used in this research will be primary data gathered in November December 2018. For ideal the sampling size to include the whole population as the respondents of the research but it has very low possibility to do. Based on BPS Jawa Barat in its publication, the size of population as the target research respondents in 2015 was \pm 565.892 people. To get the number of samples used in this research, the author uses the table below as a guide for determining the ideal sampling size, with $90 \%$ of confidence, $10 \%$ margin of error.

Secondary data is also needed to enrich the information to support the research. This research also collects data from secondary resources to support the research, such as journals and research publications that relevant to the research topic. To measure the affected, the variable research to financial literacy index and investment decision using the data collected from the questionnaires with the following order:

\section{a. Pilot Test}

Pilot test is used to minimize the probability of respondents facing problems in filling all the questions and problems in recording the data [2].

b. Questionnaire Distributions

The questionnaire is combining several types of question to get the best results from respondents as shown on the table below.

TABLE I: RESEARCH VARIABLES

\begin{tabular}{lll}
\hline \hline \multicolumn{1}{c}{ Code } & \multicolumn{1}{c}{ Variable } & \multicolumn{1}{c}{ Type of question } \\
\hline Q1 & Gender & Multiple choice \\
Q2 & Age & Multiple choice \\
Q3 & Education level & Multiple choice \\
Q4 & Occupation & Multiple choice + open-ended \\
Q5 & Location & Short Answer \\
Q6 & Education Background & Multiple choice + open-ended \\
Q7 & Income & Multiple choice \\
Q8-18 & Attitude and behavior & Linear scale \\
Q19-26 & Knowledge & Multiple choice ( true-false) \\
Q27-31 & information & Multiple choice + open ended \\
Q32-39 & preference & Multiple choice + multiple choice grid \\
\hline \hline
\end{tabular}

\section{Data Processing}

After the number of respondents already complete, the next step is processing descriptive data and statistic data using statistical analysis tools for measuring the effected between all variable.

\section{Hypothesis Development}

Based on the stated purpose of the study and on the research questions, the following hypotheses are formulated:

a. Demographic factor to financial literacy index

H1: demographic factor has significant effect on financial literacy index

H0: demographic factor has not significant effect on financial literacy index

b. Financial knowledge to financial literacy index

$\mathrm{H1}$ : financial knowledge has significant effect on financial literacy index

H0: financial knowledge has not significant effect on financial literacy index

c. Financial Behavior to Financial Literacy Index

$\mathrm{H} 1$ : financial behavior has significant effect on financial literacy index

H0: financial behavior has not significant effect on financial literacy index

d. Financial attitude to financial literacy index
H1: financial attitude has significant effect on financial literacy index

H0: financial attitude has not significant effect on financial literacy index

e. Demographic to investment decision

H1: demographic factor has significant effect on investment decision

H0: demographic factor has not significant effect on investment decision

f. Financial knowledge to investment decision

$\mathrm{H} 1$ : financial knowledge has significant effect on investment decision

$\mathrm{H} 0$ : financial knowledge has not significant effect on investment decision

g. Financial behavior to investment decision

$\mathrm{H} 1$ : financial behavior has significant effect on investment decision

H0: financial behavior has not significant effect on investment decision

h. Financial attitude to investment decision

H1: financial attitude has significant effect on investment decision

H0: financial attitude has not significant effect on investment decision

i. Information to investment decision

$\mathrm{H} 1$ : information has significant effect on investment decision

H0: information has not significant effect on investment decision

\section{VARIABLES DESCRIPTION}

\section{A. Financial Literacy}

Financial literacy is a combination between 2 dimensions, first dimension understands of financial aspect and the second is application the financial aspect in real life it means that an individual has to be able and confident to apply his or her financial knowledge in making financial decisions [3]. Authority is a series of processes or activities to increase knowledge, confidence and skills of consumers and the wider community so that they can manage finances better. In addition, having good financial knowledge can avoid financial problems for each individual.

\section{B. Financial Behavior}

Financial behavior uses insights from the field of psychology and applies them to the actions of individuals in trading and other financial applications. Financial behavior is influenced by financial knowledge, skill and financial belief of individual. By increasing in financial knowledge affects participation in financial activities.

\section{Financial Attitude}

Financial Attitude Financial is a state of mind, opinion, and judgment of a person about finances [4]. The result of the Ameliawati \& Setyani claim that Financial Attitude has affected to financial literacy, that mean if people with a good financial attitude will have good financial literacy as well. Otherwise if people who have a lack of financial attitude, will have an impact on low financial literacy. 


\section{Information}

Individuals who have low financial literacy levels and lack of information limitation do not always make bad financial decisions, they can seek advice and advice from experts, these suggestions can be an input and learning for them in determining their financial goals [5].

\section{E. Demographic Factors on Financial Literacy}

Demographic factor is gender, age, Material status, occupation, educational level, income, spending. In this research there some variables be used is gender, age, background educational, education level, income, spending, occupation [6].

1. Gender

Financial literacy is even more prevalent among women than men [7]. In addition, research find that women learn personal finance from their parents, yet women are less knowledgeable than man [8].

\section{Age}

Grouping by the age found that less than $20 \%$ of middleaged college-educated women were able to answer a basic compound interest question compared to about $35 \%$ of college-educated males of the same age [9] [10].

3. Educational background

Business-major students have better understanding on financial and investment matters compared to other nonbusiness major and claim that on average business major answered more than half of the questions correctly [8].

4. Income

Income variable has a significant effect on investment decisions can be accepted to the respondent [11].

\section{Educational level}

Each Investor has a different level of education so that in determining how to invest will vary depending on the level of education [12] [13]. Higher the level of education of individual investors, the higher the tolerance for risk in decisions [14] [15] [16] [17].

\section{Occupation}

The occupation by the respondent not significant to investment decision [18].

\section{F. Capital Market}

Capital markets have two functions for a country namely economic and financial function. To function as an economic support for a capital market country, it becomes a forum that provides facilities to bring together two parties to carry out the interests of transactions between investors and issuers. Whereas in the financial function, the capital market provides an opportunity to obtain profits (return) for the owner of the fund, according to the characteristics of the chosen investment.

\section{G. Investment}

The definition of investment is a commitment to a number of funds or other resources carried out at this time that are expected to gain a number of benefits in the future [19]. There are some investment products, namely:

\section{Stock}

Shares are a sign of investor participation to provide capital / funding to a company that has become an issuer listed on a stock exchange. Of all capital market products, shares are the most popular instruments and are understood by investors. This is because the capital market product is a product that offers a very attractive rate of return for investors.

\section{Mutual Fund}

Mutual funds are capital market investment products with a mechanism for collecting funds from investors conducted by funding managers. Funds collected will be invested in the portfolio of securities.

3. Bond and Sukuk

Basically, sukuk is a sharia bond. Islamic bonds are securities issued and represent investor ownership of assets that are the basis for issuing underlying assets without forgetting the application of Islamic principles, therefore the process and utilization of sukuk must be based on Islamic law (Sharia). Bonds in Indonesia are divided into 2 types based on the investment period, for a period of less than 1 year, a bond is called a state issuance letter (SPN), while for a period of 1- 10 years the type of bond is a government bond (SUN).

\section{Exchange Trade Fund (ETF)}

ETF is portfolio investment products that are admitted to listing or trading on a regulated exchange. An ETF provides investors with exposure to a diversified basket of shares or other financial products. ETFs aim to replicate the performance of a specific index; this index can be a blue chip, a regional, or a sector index.

\section{Derivative}

Derivative is a financial contract traded between two or more parties to buy or sell assets/commodities at an agreed time and price. The value of derivatives in the future is strongly influenced by basic assets in the Spot Market.

\section{ANALYSIS PROCESS}

The questionnaire was conducted and gathered 155 respondents from varied community spread in Bandung Area and surrounding. The questionnaire result it dominated by $52.3 \%$ female and most of them are generation $\mathrm{Y}$ or millennial generation. As much as $31.6 \%$ of the respondents had engineering educational background and graduated with bachelor's degree, with income range between Rp. 2,500,001 - Rp. 5,000,000. Yet also 46\% of the respondents now is a student who stay in Bandung. After all data was gathered and validated using $r$ table based on the number of respondents equals to 0.157 with $5 \%$ significant value, the Cronbach alpha equals to 0.716 which exceeds the requirement for reliability test.

\section{A. Validity Test}

Validation tests were carried out on the results of the questionnaire 26 items that were part of the questionnaire. To measure the validation of the data collected using a comparison between $r$ table and $r$ count. To determine whether valid data can be seen from the calculated $r$ value obtained from the results of testing the data using SPSS. If $r$ count $>\mathrm{r}$ table eats the data can be declared valid. In this research the $r$ table used was determined based on the number of $\mathrm{N}$ obtained as many as 155 respondents using a significance value of $5 \%$, then the $r$ table value obtained was 0.157 . 


\section{B. Reliability Test}

Reliability test functions to analyze each questionnaire question which is an indicator of a variable or construct. Question items are said to be reliable or reliable if someone's answer to the question is consistent. From the test results using the SPSS Cronbach Alpha value of 0.716 or above 0.6. Then it can be concluded that 26 questions contained in the questionnaire were stated to be reliable.

\section{Multicollinearity Test}

In the process of testing multicollinearity using SPSS, to indicate the occurrence of multicollinearity in multiple linear regression models seen from the table coefficients, tolerance values and VIF (Variance Inflated factors). If the Tolerance value $>0.10$ and VIF value $<10$ can be concluded there is no multicollinearity in multiple linear regression models. To measure the occurrence of multicollinear between variable values generated from Pearson Correlation $<0.7$. If there is a Pearson value $>0.7$, multicollinearity occurs in both variables.

\section{Heteroscedasticity Test}

Heteroscedasticity test is a test that is used to determine whether there is a classic assumption of heteroscedasticity deviation, namely the existence of variance inequalities from residuals for all observations in the regression model on research data. To test heteroscedasticity, the authors used the Spearman test method. The significant value used in this research is $5 \%$ or 0.05 with 2 side-tests. If the residual value is generated from the independent variable $>0.05$ It can be concluded that there is no Heteroscedasticity.

\section{E. Multiple Regression Test}

This test is conducted to determine whether or not there is a relationship between variables in a multiple regression equation. As a basis for the decision to do this test if the Sig $F$ value $<0.05$, it can be concluded that there is a significant relationship of the independent variable to the dependent variable.

\section{F. $\quad$ F-test (Stimulant)}

In this research the authors used the $F$ test as a test method of the significance relationship between the independent variable and the dependent variable simultaneously in the multiple linear regression equation built in this research. As a basis for the decision of this $F$ test if the value of sig $<0.05$ and the value of $F$ count $>F$ table then the multiple linear regression equation that is built has a significant relationship on the independent variable to the dependent variable. To find out the value of the $\mathrm{F}$ table the formula is used:

\section{Criteria:}

$$
\text { 1. Accept } \mathrm{H} 0 \text { if } \mathrm{F} \text { count }<\mathrm{F} \text { table }
$$$$
\text { 2. Reject } \mathrm{H} 0 \text { if } \mathrm{F} \text { count }>\mathrm{F} \text { table }
$$

TABLE II: F-TEST RESULT

\begin{tabular}{|c|c|c|}
\hline Model & Hypothesis & $\begin{array}{c}\text { Multiple Linear Regression } \\
\text { Result }\end{array}$ \\
\hline Model 1 & $\begin{array}{l}\text { Hl: age, gender, education level, occupation, } \\
\text { education background, income, financial } \\
\text { attitude, financial behaxiour, financial } \\
\text { knowledge and information factor has } \\
\text { significant effect on financial literacy index. } \\
\text { H0: age, gender, education level, occupation, } \\
\text { education background, income, financial attitude, } \\
\text { financial behavior, financial lonowledge and } \\
\text { information factor has not significant effect on } \\
\text { financial literacy index. }\end{array}$ & $\begin{array}{l}\text { F value calculated generated } \\
3,167>1,897 \mathrm{ftable} \text { then } \\
\mathrm{H} 0 \text { is rejected, } \mathrm{Hl} \text { is } \\
\text { accepted }\end{array}$ \\
\hline Model 2 & $\begin{array}{l}\text { Hl: age, gender, education level, Occupation, } \\
\text { Education background, and income factor has } \\
\text { significant effect on financial literacy index } \\
\text { H0: age, gender, education level, Occupation, } \\
\text { Education background, income, factor has not } \\
\text { significant effect on financial literacy index. }\end{array}$ & $\begin{array}{l}\text { F value calculated value is } \\
4.509>2.160 \text {, the } \\
\text { hypothesis } \mathrm{H} 0 \text { is rejected } \\
\text { and } \mathrm{Hl} \text { is accepted. }\end{array}$ \\
\hline Model 3 & $\begin{array}{l}\text { Hl: age, gender, education level, Occupation, } \\
\text { Education background, income, financial } \\
\text { attitude, financial behaxiour, financial } \\
\text { knowledge and information factor has } \\
\text { significant effect on investment decision. } \\
\text { H0: age, gender, education level, Occupation, } \\
\text { Education background, income, financial } \\
\text { attitude, financial behavior, financial } \\
\text { knowledge and information factor has not } \\
\text { significant effect on Investment decision. }\end{array}$ & $\begin{array}{l}\text { F value is } 20,936>1,897, \\
\text { then } \mathrm{H} 0 \text { is rejected and } \mathrm{Hl} \text { is } \\
\text { accepted. }\end{array}$ \\
\hline Model 4 & $\begin{array}{l}\text { Hl: age, gender, education level, occupation, } \\
\text { education background, and income factor have } \\
\text { significant effect on Investment decision. } \\
\text { H0: age, gender, education level, occupation, } \\
\text { education background, income, factor has not } \\
\text { significant effect on investment decision. }\end{array}$ & $\begin{array}{l}\text { F value calculated value is } \\
3.684>2.160 \text {, the hypothesis } \\
\mathrm{H} 0 \text { is rejected and } \mathrm{Hl} \text { is } \\
\text { accepted. }\end{array}$ \\
\hline Model 5 & $\begin{array}{l}\text { H1: financial attitude, financial behaviour, } \\
\text { financial knowledge and information factor } \\
\text { has significant effect on investment decision } \\
\text { H0: financial attitude, financial behavior, } \\
\text { financial knowledge and information factor } \\
\text { has not significant effect on Investment } \\
\text { decigion. }\end{array}$ & $\begin{array}{l}\text { F value equals to } 47.451 \text { > } \\
2.432 \text { can be stated that } \mathrm{H} 0 \\
\text { is rejected and } \mathrm{Hl} \text { is } \\
\text { accepted. }\end{array}$ \\
\hline
\end{tabular}

\section{G. T-test (Partial)}

As basis for the decision of this $t$ test if the value of $\operatorname{sig}<$ 0.05 and the value of $t$ count $>t$ table then the multiple linear regression equation that is built has a significant relationship on the independent variable to the dependent variable. To find out the value of the $\mathrm{F}$ table the formula is used:

\section{Criteria:}

$\mathrm{H} 0$ : the variable $\mathrm{X}$ has not significant effect on Variable $\mathrm{Y}$ $\mathrm{H} 1$ : the variable $\mathrm{X}$ has significant effect on variable $\mathrm{Y}$

1. Accept H0: $-t$ table $<$ t count $<$ t table

2. Reject H0: $\mathrm{t}$ table $<\mathrm{t}$ count

TABLE III: MODEL 1 T-TEST RESULT

\begin{tabular}{ll}
\hline \hline \multicolumn{1}{c}{ Variables } & \multicolumn{1}{c}{ Result } \\
\hline Age to financial literacy (X1.1) & No partial effect \\
Gender to financial literacy (X1.2) & No partial effect \\
Education level to financial literacy (X1.3) & Has partial effect \\
Occupation to Financial literacy (X1.4) & No partial effect \\
Education Background to financial literacy (X1.5) & Has partial effect \\
Income to financial literacy (X1.6) & No partial effect \\
Financial Attitude to financial literacy(X2) & No partial effect \\
Financial Behaviour to financial literacy (X3) & No partial effect \\
Financial knowledge to Financial literacy(X4) & Has partial effect \\
Information to financial Literacy (X5) & No partial effect \\
\hline \hline
\end{tabular}

TABLE IV: MODEL 2 T-TEST RESULT

\begin{tabular}{ll}
\hline \hline \multicolumn{1}{c}{ Variables } & \multicolumn{1}{c}{ Result } \\
\hline Age to financial literacy (X1.1) & No partial effect \\
Gender to financial literacy (X1.2) & No partial effect \\
Education level to financial literacy (X1.3) & Has partial effect \\
Occupation to Financial literacy (X1.4) & No partial effect \\
Education Background to financial literacy (X1.5) & No partial effect \\
Income to financial literacy (X1.6) & No partial effect \\
\hline \hline
\end{tabular}


TABLE V: MODEL 3 T-TEST RESULT

\begin{tabular}{ll}
\hline \hline \multicolumn{1}{c}{ Variables } & \multicolumn{1}{c}{ Result } \\
\hline Age to investment decision (X1.1) & No partial effect \\
Gender to investment decision (X1.2) & No partial effect \\
Education level to investment decision (X1.3) & No partial effect \\
Occupation to Investment decision (X1.4) & No partial effect \\
Education Background to investment decision (X1.5) & No partial effect \\
Income to investment decision (X1.6) & Has partial effect \\
Financial Attitude to investment decision(X2) & No partial effect \\
Financial Behaviour to investment decision (X3) & No partial effect \\
Financial knowledge to Investment decision(X4) & Has partial effect \\
Information to investment decision (X5) & Has partial effect \\
\hline \hline & \\
\multicolumn{1}{c}{ TABLE VI: MoDEL 4 T-TEST RESULT } & \\
\hline \hline
\end{tabular}

TABLE VII: MODEL 5 T-TEST RESULT

\begin{tabular}{ll}
\hline \hline \multicolumn{1}{c}{ Variables } & \multicolumn{1}{c}{ Result } \\
\hline Financial Attitude to investment decision(X2) & Has partial effect \\
Financial Behaviour to investment decision (X3) & No partial effect \\
Financial knowledge to Investment decision(X4) & Has partial effect \\
Information to investment decision (X5) & Has partial effect \\
\hline \hline
\end{tabular}

\section{RESULT AND DISCUSSION}

\section{A. Financial Literacy}

For the financial knowledge resulting value of 13.48 of 16 which can be explained on average the respondents can answer correctly as many as 5 out of 8 questions. The standard deviation data generated is large enough so that it can be concluded that the greater the standard deviation value generated eats the greater the variation in the data from the questionnaire. The financial behavior has average value generated from the answers of the respondents on the questionnaire questions generated value of $4.07-5.1$ from 6 scale then it can be concluded that the financial behavior of the respondents in the research are in a positive state. For financial attitude the results of calculations using SPSS can be seen the mean value generated above score 4 of 6 for each item statement in the questionnaire, it can be concluded that the average respondent has a positive financial attitude. Based on the questionnaire, the result of financial literacy questionnaire is shown on table 2 below:

TABLE VIII: FINANCIAL LITERACY RESULT

\begin{tabular}{cll}
\hline \hline \multicolumn{1}{c}{ Variable } & Parameter & Result \\
\hline \multirow{3}{*}{ Financial Knowledge } & High & $53 \%$ \\
& Medium & $35 \%$ \\
& Low & $12 \%$ \\
\hline \multirow{2}{*}{ Financial Behavior } & Positive & $96 \%$ \\
\cline { 2 - 3 } & Negative & $4 \%$ \\
\hline \multirow{2}{*}{ Financial Attitude } & Positive & $90 \%$ \\
& Negative & $10 \%$ \\
\hline \hline
\end{tabular}

\section{B. Investment Product Preference}

For the average information source, each respondent has 3-4 data sources. While the second question states that the average respondent has 3-4 types of investment products in Indonesia, the result shown on the Figure 1 below:

\section{INVESTMENT PRODUCT}

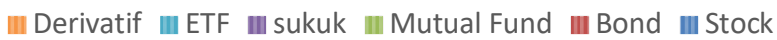

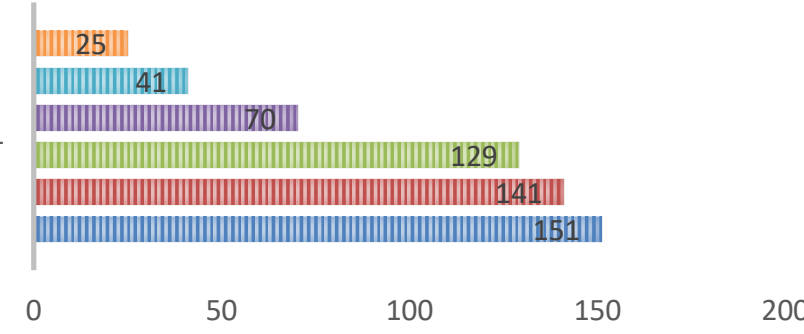

Fig 1. Respondent's Investment Product

\section{Information Source Preference}

As seen on the Figure 2 below the most widely used source of information by respondents is 103 social media respondents. A total of 128 respondents received information and knowledge about the capital market from schools, colleges, and capital market schools.

\section{INFORMATION SOURCE \\ w others \\ in school, university, capital market school \\ iil collegue \\ in social media}

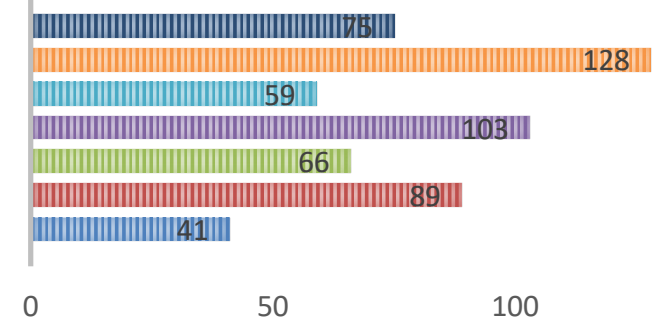

Fig 2. Respondent's Information Source

\section{Preference Descriptive}

In the preference, the author question items provide several factors that generally influence investment decisions. Of the 6 factors the authors asked respondents to rank 6 factors. If the respondent ranks 1 on one of the factors, then this factor is the most influential factor in the investment decision for the respondent. The result shown on the figure below: 


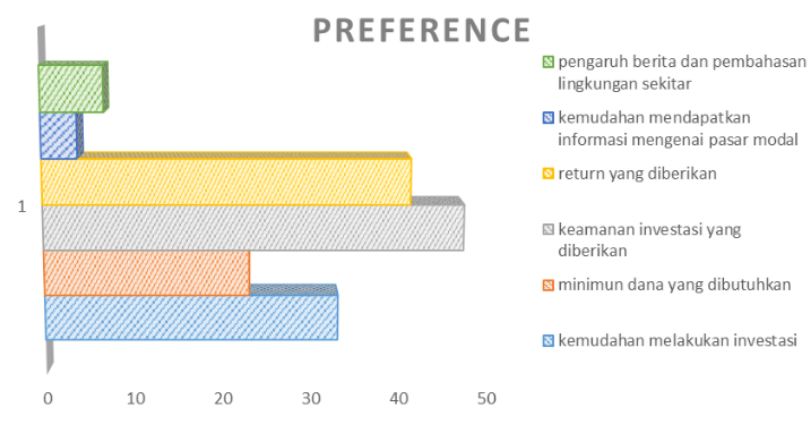

Fig 3 Respondent's preference

\section{CONCLUSIONS}

Multiple linear regressions testing 5 multiple linear regression models is done by using SPSS software on several independent variables on the dependent variable financial literacy and investment decisions. In this research 2, multiple linear regression models were conducted on the dependent variable financial literacy. From the results of the F test, all independent variables have a significant relationship to the dependent variable simultaneously. Then it can be concluded that for changes that occur in demographic factors, financial attitude, financial behavior, financial knowledge and information on children increase financial literacy level. Also, in this research, 3 multiple linear regression models were made which were used to perform regression tests on the dependent variable investment decision. From the results of the $3 \mathrm{~F}$ test on the dependent variable Investment decision, there are simultaneous significant effects by demographic factors, financial attitude, financial behavior, financial knowledge and information on investment decisions. Then it can be concluded that the simultaneous changes that occur in factors that have an influence on investment decisions can increase the number of investment decisions.

\section{REFERENCES}

[1] Hox, J. J., \& Boeije, H. R. . "Data collection, primary versus secondary.", 2005.

[2] Saunders, M., Lewis, P., Thornhill, A., \& Wilson, J. "Business Research Methods. Financial Times, London.”,2009.

[3] Huston, S. J.. Measuring financial literacy. Journal of Consumer Affairs, 44(2), 296-316.2010.

[4] Ameliawati, M. \& Setiyani, R. " The Influence of Financial Attitude, Financial Socialization, and Financial Experience to Financial Management Behavior with Financial Literacy as the Mediation Variable. Department of Economic Education. Faculty of Economics. Semarang State University. Indonesia..” 2018.

[5] Calcagno, R. \& Monticone, C.. "Financial literacy and the demand for financial advice." 2015.

[6] Kelmara, V. M., Potrich, A., \& Kirch, G.’Determinants of Financial Literacy: Analysis of the Influence of Socioeconomic and Demographic Variables.”,2015.

[7] Lusardi A., Mitchell O.S. "Financial literacy and retirement preparedness: Evidence and implications for financial education." 2008.

[8] Chen, H., \& Volpe, R. “ An Analysis of Personal Financial Literacy among College Students.', 1998S. Chen, B. Mulgrew, and P. M. Grant, "A clustering technique for digital communications channel equalization using radial basis function networks," IEEE Trans. on Neural Networks, vol. 4, pp. 570-578, July 1993.
[9] Zissimopoulos, J. M., Karney, B. and Rauer, A.. "Marital histories and economic well-being." Michigan Retirement Research Center Research Paper No. WP 180. 2008.

[10] Fonseca, R., M., K. J., Z., G., \& Z., J. “ What explains the gender gap in financial literacy? The role of household decision making.' Journal of Consumer Affairs, 46(1), 90-106. 2012.

[11] Rasyid, R. Linda, M. R..,Patrisia D.., Fitra, H.., Susanti, Y. "The Effect of the Locus of Control, Financial Knowledge and Income on Investment Decisions", 2018.

[12] Lutfi . "The Relationship between Demographic Factors and Investment Decision in Surabaya",2010.

[13] Obamuyi T.M.,. "Factors Influencing Investment Decisions in Capital Market: A Study of Individual Investors in Nigeria.' 2013.

[14] Lewellen,W., Lease R.C., Schlarbaum.G. G.,.” Pattern of Investment Strategy and Behavior among Individual Investors." 1977.

[15] Schooley, D \& Worden,D,. "Investors'Asset Allocations versus LifeCycle Funds".1999.

[16] Danella, J., Rahadi, R.A. and Helmi, I. "A conceptual study on the impact of financial literacy level to household wealth in Bandung." Journal of Humanities, Language, Culture and Business 1.6 2017.

[17] Rahadi, R.A. Danella, J. and Okdinawati, L. "The Correlation between Financial Literacy and Family Wealth Distribution in Bandung." European Journal of Business and Management Research 4.22019.

[18] Geetha, N. \& Ramesh, M. “ A Study on Relevance of Demographic Factor in Investment Decisions." Department of Business Administration, Annamalai University, Tamilnadu, India,2012.

[19] Tandelilin, E.. "Portofolio dan Investasi, Teori dan Aplikasi." Edisi Pertama. Yogyakarta: Kanisius,2010.C. Y. Lin, M. Wu, J. A. Bloom, I. J. Cox, and M. Miller, "Rotation, scale, and translation resilient public watermarking for images," IEEE Trans. Image Process., vol. 10 , no. 5, pp. 767-782, May 2001.

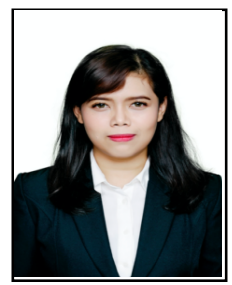

Yustitia Fitria is a fresh graduated in Master degrees. Before she takes master degree, she graduated from Parahyangan University of Bandung, with Bachelors degrees in Industrial Engineering in march 2016. After graduation, in august 2017 she started studied master degree in Master of Business Administrations, Institut Teknologi Bandung and graduated the master degree in April 2019 with concentration major in finance field. She was born in Surabaya, capital city of East Java, Indonesia. At April 10 $0^{\text {th }}, 1992$.

Yustitia was have experience internship in Indonesian Aerospace in 2013 while studies in bachelor degree. While internship in Indonesian Aerospace she placed as a part of quality control staff. As final feedback for the Indonesian Aerospace, she make a report with the team as the title was "Perancangan Usulan Perbaikan Drive Rib Airbus A-380 Spirit Dengan Metode Six Sigma-Dmaic Pada PT Dirgantara Indonesia (Persero)" Afterward in 2018 during study period in master degree, she got opportunity to do internship in Indonesia Stock Exchange started in May 2018 until July 2018 as a part of Development and support trading division as a internship staff. As a feedback for internship to Indonesia Stock Exchange, she was make a final report title "Business Strategy Analysis for Distribution Data Feed Indonesia Stock Exchange". For the Certification, Ms. Fitria got the certification in a Capital Market field as a Investment Manager Representative in 2018.

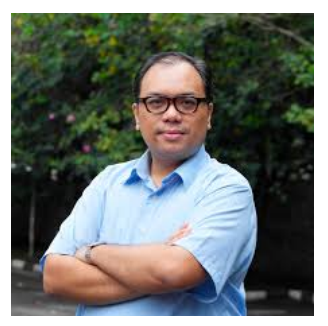

Dr. Raden Aswin Rahadi is a faculty member at the School of Business and Management, Institut Teknologi Bandung (SBM-ITB).

A real estate and property veteran, he was previously appointed as a Senior Lecturer at School of Maritime Business \& Management, Universiti Malaysia Terengganu, Malaysia (2016-2017); Managing Partner at RA+ Consulting (20102006); Senior Associate at Northstar Pacific \& Partners (2004-2010); and Junior Business Development Manager at BSD City (2003-2004).

He holds a Doctorate degree with Distinction (Cum Laude) in Management Science from the School of Business and Management, Institut Teknologi Bandung, Indonesia; Master of Management degree from Swiss German University, Indonesia; Master of Business Administration degree from Fachhochschule Konstanz - Hochschule fur Technik, Wirtschaft und Gestaltung, Germany; and Bachelor of Engineering degree from School of Architecture, Planning, and Policy Development, Institut Teknologi 
Bandung, Indonesia

His research interests are in the fields of real estate, finance, management, consumer behavior, consumer preference, marketing, entrepreneurship, ecommerce, financial planning, and city \& quality of life improvements.

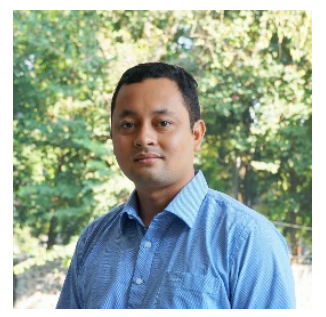

Kurnia Fajar Afgani is the full -time lecturer in Business Risk and Finance group. His research interests are Islamic Finance and Business Economics. His teaching interest includes Business Economics, and Islamic Finance. He graduated with Master of Business Administration from the School of Business and Management (SBM) ITB, and has also obtained a Bachelor of Business Administration from Parahyangan Catholic University (Unpar). He worked for the Bank bjb Syariah Company for around 10 years Prior to taking this position as a faculty member of the SBM ITB until present.

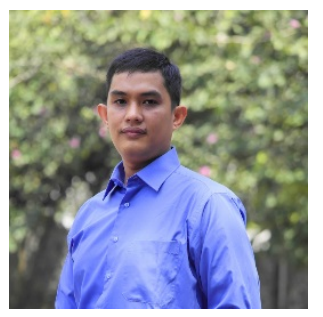

Nur Arief Rahmatsyah Putranto graduated from Industrial Engineering Institut Teknologi Bandung for Bachelor Degree and Human Resources Management Griffith University for Master Degree. He has expertise in Human Capital Management and Cross Cultural Management and has experience as consultant in several companies in HCM area.

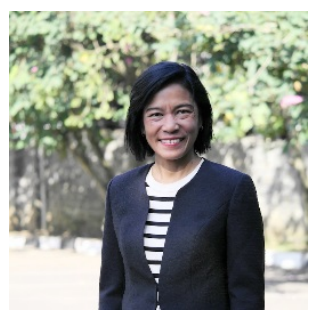

Isrochmani (Nani) holds a Master's in Accounting from the University of Oregon, USA in 2003; she completed a Bachelor's degree in the same field at the University of Indonesia in 1984. Her Doctoral degree from Padjadjaran University.

Her research interests are in the field of Financial Accounting and Managerial Accounting. Nani has joined the Business Risk with expertise / specialization in the field of Accounting. and Finance Management Expertise Group,

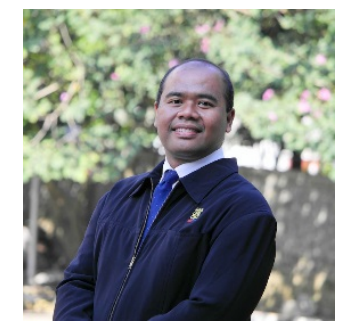

Taufik Faturohman is currently a lecturer at the School of Business and Management Institute of Technology Bandung (SBM ITB). He received a $\mathrm{PhD}$ in Economics and Finance from Curtin Business School, Curtin University of Technology, Western Australia. The title of his dissertation was "An Examination of the Growth of Islamic Banking in Indonesia from 2003 to 2010". Taufik obtained his MBA from ITB, and graduated with honors (cum laude). He earned a Bachelor's degree in Materials Engineering, also from ITB. 